Est Ag 46 (2011) 203-231

\title{
Presencia de la carta 22 de san Jerónimo en el Praeceptum de san Agustín
}

\author{
Pío DE LuIS VizCAÍnO, OSA*
}

RESUMEN: Cuando san Agustín escribió el praeceptum o Regla para los siervos de Dios, conocía ya la célebre Carta 22 de san Jerónimo a la virgen Estoquia. De ella había tomado los datos sobre el monacato egipcio que utiliza contra los maniqueos en la obra De moribus ecclesiae catholicae. El dato justifica formular la pregunta de si la carta jeronimiana influyó de alguna manera en la composición del texto monástico agustiniano. Las abundantes coincidencias en los temas tratados, aunque no siempre en el modo de tratarlos, hace razonable la respuesta positiva.

PALABRAS CLAVE: Praeceptum de san Agustín; ep. 22 de san Jerónimo; monacato.

ABSTRACT: When Saint Augustine wrote the Praeceptum or Rule for the Servants of God, he already knew the famous Letter 22 of Saint Jerome, Ad Eustochium de Custodia Virginitatis. This text provided him with the data on Egyptian monasticism used in the work against the Manicheans, De Moribus Ecclesiae Catholicae. Its date justifies the query if Jerome's letter influenced the composition of the Augustinian monastic text in some ways. The abundance of corresponding topics dealt with, although not always in the same manner, allows a reasonably positive answer.

KEY WORDS: St. Augustine's Praeceptum; St. Jerome's Letter 22; monasticism.

* Profesor de Patrología del Estudio Teológico Agustiniano de Valladolid. pioluvi@hotmail.com 
Entre las cartas de san Jerónimo, una de las más conocidas es la $22^{1}$, denominada por él también libellus de uirginitate seruand $a^{2}$. Si al biógrafo de Jerónimo le informa sobre su juventud romana y la posterior tentación en el desierto $(22,7)$, si al historiador del monacato antiguo le ofrece una valiosa información sobre el monacato egipcio (22,33-36), al investigador de las relaciones entre cultura cristiana y cultura clásica le obsequia con su célebre sueño en el desierto de Calcis en que se vio acusado de ser ciceroniano, no cristiano $(22,30)$, tres datos "dignos de figurar en toda antología jeronimiana" 3 . Pero en su tiempo la carta fue estimada sobre todo por su exhortación a vivir en castidad. Escrita en el 384, nominalmente estaba dirigida a Eustoquia, hija de Paula, una noble matrona romana que, al quedar viuda, emprendió un tipo de vida ascético y formó parte del grupo de nobles romanas que se reunían en el Aventino bajo la guía espiritual de san Jerónimo ${ }^{4}$. Sin embargo, según el parecer de no pocos estudiosos, en la intención de su autor se trataba más bien de una carta abierta al conjunto de vírgenes cristianas provenientes de familias aristocráticas ${ }^{5}$. A pesar de ser objeto de duras críticas ${ }^{6}$, por su carácter práctico la exhortación acabó convirtiéndose en manual clásico sobre la guarda de la virginidad en ambientes monásticos.

\footnotetext{
${ }^{1}$ Cf. CSEL LIV, 143-211. Un comentario de la carta se puede leer en A. DE VOGÜÉ, Histoire littéraire du mouvement monastique dans l'antiquité 1. Du Cerf, Paris 1991, pp. 235-325.

${ }^{2}$ Así en ep. 31,2 y 52,17. En ep. 49,18, 123,17 y 130,19, lo designa como liber. Como libellus la considera en los parágrafos 2 y 22 de la carta misma. En su obra De viris inlustribus 135, se refiere a ella como Ad Eustochium de uirginitate seruanda.

${ }^{3}$ A. DE VOGǗ, Histoire littéraire, $I$, p. 235.

${ }^{4}$ Sobre esta joven, cf. Nuovo Dizionario Patristico e di antichità cristiane, Marietti, Genova-Milano 2006, A-E, pp. 1886-1887.

5 A. CAIn, The Letters of Jerome. Ascetism, Biblical Exegesis and the Construction of Christian Authority in late Antiquity, Oxford University Press 2009, p. 101. Esta opinión es compartida por otros autores. J. D. N. Kelly pone la carta 22 en el contexto de una campaña ascética que Jerónimo impulsaba en Roma en los años 383-384 con la aprobación del papa Dámaso (Jerome. His Life, Writings and Controversies, London 1975, p. 101). R. Byrne juzga que Jerónimo usa la carta como plataforma para proclamar su programa ascético y para exponer la corrupción que, a su parecer, afectaba a muchos cristianos de la sociedad romana, incluyendo ascetas y clérigos (The Cenobitic Life. A Digression in Jerome's Letter Twenty-Two to Eustoquium, en Downside Review 105 [1987] 277-293: 278). A su vez, Laurence Patrick escribe: "Jerôme savait bien fort que sa lettre n'allait pas demeurer entre les mains du cercle familial de sa correspondante, et qu'elle allait connaître une large diffusion: il pouvait en être assuré, lui qu'avait rendu célèbre son experience du désert $(22,7)$, celle de l'exégèse, et qui surtuot était devenue le secretaire du pape Damase" (L'épître 22 de Jerôme et son temps, en Epistulae antiquae $I$. Actes du $\mathrm{I}^{\mathrm{er}}$ Colloque international "Le genre epistolaire antique et ses prolongements européens", Tours 18-19 septembre 1998, éd. par Leon NADJO and Elisabeth Gavollle, Peeters, Louvain-Paris 2000, 63-83:64). Cf. también CHRISTA KruMEICH, Hieronymus und die christlichen Feminae clarissimae, Bonn 1993, p. 94.

${ }^{6} \mathrm{De}$ ellas tiene que defenderse su autor en ep. 130,19. En el artículo antes citado, L. Patrick investiga en qué ha podido desagradar el escrito carta y quiénes pudieron sentirse ofen-
} 
Junto a la virginidad y en relación con ella, san Jerónimo trata otros numerosos temas como el ayuno, la oración, la lectura de la palabra de Dios, las salidas de casa, la austeridad, etc., que aparecen también en el praeceptum -en la terminología de L. Verheijen ${ }^{7}-\mathrm{o}$-con designación más tradicional- en la "Regla a los siervos de Dios" de san Agustín. Es dato seguro que, al escribir su Regla monástica, el obispo de Hipona conocía la mencionada carta de san Jerónimo. En ella había bebido para la descripción que hace del monacato católico en De moribus ecclesiae catholicae et de moribus manichaeorum ${ }^{8}$. Constatado ese dato, cabe plantearse la cuestión de si esa misma carta jeronimiana dejó alguna huella en el praeceptum agustiniano ${ }^{9}$. La cuestión está justificada porque el santo no disponía de ningún otro texto similar en lengua latina en que inspirarse a la hora de componer una norma de vida para su monasterio. Al menos no lo conocemos.

La dependencia de un texto respecto de otro puede conocerse por afirmaciones explícitas, ya sea de los propios autores, ya sea de otros, pero en nuestro caso no existen. Ante esta realidad, no queda otra vía que la crítica

didos, llegando a la conclusión de que la carta, tal como se presenta, no podía no acabar en escándalo (p. 82). El mismo Rufino de Aquileya, antes amigo íntimo de Jerónimo, la critica, añadiendo que todos estaban contra Jerónimo por haber dado armas a los enemigos de la Iglesia (cf. Apologia contra Hieronymum, 2,5).

${ }^{7}$ La Règle de saint Augustin. I. Tradition manuscrite; II. Recherches historiques, Paris, 1967, I, pp. 11; 417-437.

${ }^{8} \mathrm{Cf}$. Mor 1,31,65-68. De hecho, los autores reconocen que es la fuente de los datos sobre el monacato que ofrece san Agustín en la obra. Cf. A. ZUMkeller, Das Mönchtum des hl. Augustinus, Würzburg $1968^{2}$, p. 348, n. 2. A. MANRIQUe, La vida monástica en san Agustín. Enchiridion histórico-doctrinal y Regla (a. 373-430), El Escorial-Salamanca 1959, p. 53, n. 50; p. 58, n. 58. L. CILleruelo El monacato de san Agustín, Valladolid 1966, p. 107ss. A. DE VoGÜÉ, Histoire littéraire du mouvement monastique dans l'antiquité 2, pp. 110-111; R. BYRNE, The Cenobitic Life, p. 277. Amplia discusión en J. K. CoYLE, Augustine's "de moribus ecclesiae catholicae", $A$ Study of the Work, its Composition and its sources, The University Press, Friburg Switzerland 1978, pp. 211-221.

${ }^{9}$ A. de Vogué sólo señala dos puntos de coincidencia entre ambos escritos: $E p .22,35$ (moderatus incessus) y 33 (nec hoc crudeliter quisquam factum putet), y Praec. 4,3 (in incessu...) y 9 (non enim et hoc fit crudeliter) respectivamente (Histoire littéraire, I, p. 291 y 410). N. Adkin, en cambio, en su obra Jerome on Virginity. A Commentary on the libellus de virginitate servanda (Letter 22), Francis Cairns, Cambridge 2003, señala siete coincidencias entre la carta 22 de san Jerónimo y la carta 211,5-16 de san Agustín, esto es, la regularis informatio, según la terminología de L. Verheijen, o versión femenina del praeceptum. Son las siguientes: ep. 22,27: Nulla diversitate notabilis / ep. 211,10: non sit notabilis habitus uester (p. 209); ep. 22,23: Aliter impudici uident oculi / ep. 211,10: impudicus oculus, impudici cordis est nuntius (p. 246); ep. 22,3: Venire superbiam de proposito, sed timorem/ ep. 211,14 sancto proposito (p. 33); ep 22,17: Carnis amor spiritus amore superatur / ep. 211,14: non carnalis sed spiritalis inter uos debet esse dilectio (p. 142); ep. 22,24: Christi ancilla / ep. 211,14: ancillis Christi (p. 218); ep. 22,29: Quod si aliquam senseris infirmiorem in fide / ep. 211,15: suscipiat infirmas (p. 269): ep. 22,35: Oboedire maioribus / ep. 211,15: matri oboediatur. 
interna para detectar la posible dependencia y, en el caso de darse, el grado de la misma. Al respecto conviene no olvidar que en el mundo antiguo no existía conciencia tan viva como en la actualidad de la propiedad intelectual y que, por tanto, un autor no se sentía obligado a dejar constancia de sus fuentes; conviene no olvidar tampoco que la dependencia puede darse aunque el autor del escrito no se percate de ello, por cuanto el caudal de conocimientos de una persona se ha formado a través de lecturas de las que no siempre guarda ya memoria. Excluidas la cita literal, la forma más evidente de dependencia y fácil de detectar, y la alusión directa, no cabe sino investigar si hay contenidos coincidentes o datos en un texto que pueden dar razón de lo que encontramos en el otro. Esta es la vía que seguiremos.

Aunque los resultados serían exactamente los mismos, lo que nos interesa no es descubrir qué puntos de la Carta jeronimiana aparecen luego en el praeceptum agustiniano, sino qué puntos del praeceptum se encuentran ya en la carta. Esta distinción puramente formal se traduce en que el orden que seguiremos en el estudio no lo marcará la carta sino el praeceptum, examinado capítulo a capítulo. No obstante, en la exposición concreta ofreceremos primero el dato jeronimiano y, a continuación, el correspondiente agustiniano, señalando tanto los puntos de convergencia entre ambos como, si es el caso, los aspectos en que divergen.

\section{Los textos comparados}

\section{a) Capítulo primero del praeceptum}

San Jerónimo escribe a Eustoquia: "No necesito inculcarte que no alardees de tus riquezas, ni te jactes de la nobleza de tu linaje, ni te consideres más que los demás.... Que el desprecio del orgullo del siglo no engendre en ti otro orgullo..." $(22,27)^{10}$. Esta idea se puede ver vertida por san Agustín en el capítulo primero del praeceptum en estos términos: "A su vez, los que eran tenidos en algo en su vida secular no menosprecien a sus hermanos que llegaron a dicha santa comunidad desde una condición de pobreza. Tampoco se muestren altivos por haber aportado a la comunidad una parte de sus bienes, ni los haga más soberbios el hecho de compartir sus riquezas en el monasterio que el disfrutarlas en la vida secular" $(1,8)$. Cierto,

\footnotetext{
${ }^{10}$ Los textos de la carta jeronimiana los tomamos de la traducción de Juan Bautista Valero (SAN JeRónimo, Epistolario. Edición Bilingüe. I. Edición preparada por J. B. V., Biblioteca de Autores Cristianos, Madrid 1993, pp. 203-260). La traducción del praeceptum agustiniano es nuestra.
} 
san Jerónimo habla de riquezas que Eustoquia aún posee, san Agustín de bienes que los religiosos han donado ya a la comunidad, pero ambos coinciden en contemplar el peligro de enorgullecerse tanto de los bienes poseídos como de la propia categoría social.

San Jerónimo recomienda a Eustoquia: "Que el desprecio del orgullo del siglo no engendre en ti otro orgullo". Estas palabras procede asociarlas a estas otras de san Agustín: "el orgullo acecha incluso a las obras buenas para hacer que perezcan" $(1,8)$. El monje dálmata advierte que la misma acción laudable de abandonar lo que produce orgullo en el siglo (las riquezas y la elevada condición social) puede engendrar orgullo; el monje de Hipona sostiene que el orgullo puede hacer que se pierdan acciones buenas. Las afirmaciones no son idénticas pero se presuponen y, por eso mismo, se complementan: si una acción buena engendra orgullo (san Jerónimo), esa acción buena desaparecerá en cuanto tal acción buena (san Agustín). San Agustín se ha limitado a hacer explícito lo que estaba implícito en san Jerónimo.

Describiendo al tercer género de monjes, el llamado remnuoth, "el más detestable y despreciado", san Jerónimo señala entre otras cosas que "del fruto de su trabajo depositan una parte para tener alimentos comunes" $(22,34)$. Algo parecido encontramos en el primer capítulo del praeceptum. A los que eran tenidos por algo en la vida secular, les recomienda "que no se muestren altivos por haber aportado a la vida común una parte de sus bienes". El contexto es diferente: san Jerónimo habla de monjes que "habitan de dos en dos o de tres en tres o de poco más", san Agustín de una comunidad ya mayor, pero coinciden en la idea de poner en común algo de lo poseído: según la carta jeronimiana, una parte del fruto de su trabajo; según el praeceptum, una parte de sus bienes ${ }^{11}$.

\section{b) Capítulo segundo del praeceptum}

A propósito de la oración escribe el monje dálmata afincado en Roma: "El Apóstol nos manda orar siempre (cf. 1 Tes 5,17)...; sin embargo, debe-

${ }^{11}$ En el caso de los monjes de que habla san Jerónimo el hecho recibe una valoración negativa: depositan una parte para tener alimentos comunes y así vivir libres, sin depender de nadie; el texto de la Regla es más difícil de interpretar: ¿por qué ponen en común sólo algo de sus bienes? ¿Qué hacen o han hecho con el resto? ¿Se han quedado con ello? Difícil de admitir, si consideramos que poco antes ha ordenado que "quienes tenían algún bien en su vida secular acepten de buen grado que sea común antes de entrar en el monasterio". Cabe pensar, pues, que al resto le habían dado un destino lícito (cf. s. 355,6; ep. 83,4). 
mos tener repartidas las horas de oración, para que, si estamos absorbidos por algún trabajo, el tiempo mismo nos amoneste a cumplir nuestro deber: las horas de tercia, sexta, nona y también laudes y vísperas" (22,37). Esta recomendación de la oración evoca la contenida en el praeceptum: "Sed asiduos a las oraciones (cf. Col 4,2; Rom 12,12) en las horas y tiempos establecidos" $(2,1)$. El breve precepto del texto agustiniano recoge los dos contenidos principales del texto jeronimiano: la vida de oración ordenada por san Pablo, y la distribución en el tiempo de momentos específicos de oración. También hay divergencias: de una parte, para recomendar la oración san Jerónimo recurre a 1 Tes 5,17 (oración incesante) mientras que san Agustín se inspira en Col 4,2/Rom 12,12 (oración asidua); de otra, el presbítero da razón de por qué las horas de oración han de repartirse a lo largo del día, indicando cuáles eran esos momentos específicos, dato que el obispo pasa por alto. Pero estas divergencias no anulan la convergencia señalada.

Al describir los usos de los monjes cenobitas, san Jerónimo escribe: "Los domingos se dedican exclusivamente a la oración y a la lectura. Cosa, por lo demás, que hacen el resto de los días, una vez terminadas las tareas" $(22,35)^{12}$. Esta misma praxis parece subyacer a lo que prescribe el praeceptum: "En el oratorio nada haga sino aquello para lo que ha sido hecho... De modo que si acaso hubiera algunos que, teniendo tiempo, quisieran hacer oración también fuera de las horas fijadas para ella, no se lo impida quien juzgue que allí debe hacerse otra cosa" $(2,2)$. La recomendación de que el religioso, una vez realizada la tarea que le fue asignada, dedique el tiempo que le sobre a la oración coincide con lo referido por san Jerónimo. Esta coincidencia básica no la anulan las evidentes divergencias que existen entre un texto y otro: mientras san Jerónimo describe una realidad, san Agustín hace una recomendación; mientras san Jerónimo indica que ese tiempo sobrante lo dedicaban a la oración y a la lectura de la Escritura, san Agustín habla sólo de la oración; mientras san Jerónimo se refiere sólo a los días de semana, excluido el domingo porque ese día no trabajaban, san Agustín no indica nada al respecto; mientras san Jerónimo no señala el lugar de la oración, san Agustín sí.

${ }^{12}$ Sobre este horario monástico, cf. A. DE VOGÜÉ, L'horaire de l'Ordo monasterii. Ses raports avec le monachisme égyptien, en Homo Spiritalis, Festgabe für Luc Verheijen OSA zu seinem 70. Geburtstag. Hrg. von Cornelius Mayer unter Witwirkung von Karl Heinz Chelius, Augutinus Verlag, Würzburg 1987, 240-258:241-243. 


\section{c) Capítulo tercero del praeceptum}

En los cenobios cuyo género de vida describe san Jerónimo se daba un trato de privilegio, en el menú y en el horario, a dos grupos de personas de riesgo: los ancianos y los niños. "Vino sólo lo beben los ancianos. A estos y a los niños (pueri) se les da a menudo un desayuno, a los unos para sostener su edad ya fatigada, y a los otros para que no se les quebrante en los mismos comienzos" $(22,35)$. Ahora bien, este mismo trato de privilegio para algunos grupos aparece también en el praeceptum. De hecho, mientras unos están obligados al ayuno y a la abstinencia, a otros se les dispensa de lo uno y de lo otro. Del ayuno: "Si alguno no puede ayunar, no tome alimentos fuera de la hora del «desayuno», a no ser que se encuentre enfermo" $(3,1)$; del ayuno o de la abstinencia: "Si aquellos a quienes su anterior régimen de vida ha hecho débiles reciben un trato diferente en alimentación..." $(3,3)$, y de la abstinencia: "Y si a quienes entraron en el monasterio procediendo de costumbres más delicadas se les conceden alimentos... que no se otorgan a otros más fuertes..." $(3,4)$. Los dos textos tienen en común el referirse a un trato de excepción al eximir del ayuno y al otorgar una dieta diferente a determinados grupos y el justificarlo por razones de salud, pero se distinguen a la hora de determinar los grupos favorecidos y los alimentos. Mientras san Jerónimo señala que el trato de excepción lo reciben los ancianos y los niños, san Agustín lo ordena para los débiles y los enfermos, independientemente de cuál sea su edad; mientras san Jerónimo habla sólo del vino permitido a los ancianos, san Agustín habla de alimentos (más delicados), sin especificar.

Entre los comportamientos que san Jerónimo conoce y alaba en los cenobios cuya vida describe, está el hecho de que "durante la comida no se produce ruido alguno" y de que "nadie habla mientras come" (22,35). El praeceptum agustiniano, en cambio, tiene que recomendar calma en el refectorio: "escuchad sin alboroto ni discusiones lo que, según costumbre, se os lea" $(3,2)$. Mientras el texto jeronimiano alude al ruido que puede proceder de objetos, el agustiniano habla de alboroto, que lo producen personas; mientras el primero se sirve del genérico "hablar", el segundo utiliza el específico "discutir". Muy probablemente en esta recomendación de san Agustín haya que ver más la respuesta a una situación concreta de la comunidad destinataria del código monástico que una prueba de inspiración en otro autor, pero no deja de ser significativo el que ambos textos coincidan en señalar este aspecto, en apariencia menor, de la marcha de una comunidad. 
En la persona de Eustoquia, san Jerónimo contempla el caso de aquellos a quienes su anterior género de vida les ha habituado a vivir de una determinada manera: "Y si replicas que has nacido de noble linaje y te has criado siempre en el lujo y entre plumas, y que no puedes prescindir del vino y de manjares exquisitos, y que, en fin, no vas a poder vivir conforme a estas leyes tan rigurosas, te replicaré: 'Pues vive según tu ley, ya que no puedes vivir conforme a la ley de Dios"' $(22,11)$. En esta descripción se pueden ver reflejados los "débiles" de que habla el capítulo tercero del praeceptum. En él san Agustín habla de "aquellos a quienes su anterior régimen de vida ha hecho débiles, [razón por la que] reciben un trato diferente en alimentación" (3,3), y de aquellos que "entraron en el monasterio procediendo de costumbres más delicadas, [a los que] se conceden alimentos, vestidos, colchones o cobertores que no se otorgan a otros más fuertes... aunque no hayan podido alcanzar la austeridad de los físicamente más robustos" $(3,4)$. La realidad contemplada en el texto de uno y otro autor es la misma. Los datos que aduce san Jerónimo, a saber, la noble cuna, el lujo, el dormir entre plumas, la incapacidad de renunciar a una determinada dieta alimenticia y de someterse a un régimen de austeridad están presupuestos en el texto del praeceptum. Las costumbres más delicadas allí indicadas se refieren al ámbito alimentario (en la carta: no poder prescindir de manjares exquisitos), al ámbito del vestuario (en la carta: criado siempre en el lujo), al ámbito del dormir (en la carta: criado entre plumas). El "no poder vivir conforme a estas leyes tan rigurosas" del texto jeronimiano tiene su equivalente en esta constatación del texto agustiniano: "aunque no hayan podido alcanzar la austeridad de los físicamente más fuertes" $(3,4)$. Pero también salta a la vista la divergencia entre ambos escritos. Consiste en la diferente respuesta que uno y otro autor dan a idéntica situación personal: san Agustín se muestra condescendiente con esas debilidades, permitiendo a quienes las sufren un cierto trato de privilegio; san Jerónimo en cambio, se muestra intransigente; el obispo considera a los que las sufren capacitados para la vida monástica y por ello los mantiene en el monasterio, el presbítero los considera incapacitados para seguir un camino de perfección.

\section{d) Capítulo cuarto del praeceptum}

El capítulo cuarto del praeceptum es el que más huellas conserva de la carta jeronimiana. Nada extraño, habida cuenta que la carta es una exhortación a la virginidad -todos los demás temas tratados allí son introducidos 
por su relación con ella-y que el capítulo cuarto del texto agustiniano trata de la castidad.

La descripción que hace san Jerónimo del porte de algunas vírgenes contiene estos rasgos: "En su vestido únicamente hay un tenue toque de púrpura, la cabeza va sujeta flojamente para que cuelgue el pelo, el calzado es rústico, el chal revolotea sobre los hombros, las mangas son estrechas y pegadas a los brazos... Esta es toda la virginidad para ellas" $(22,13)$. Esta preocupación por el porte exterior puede estar detrás del parágrafo inicial del capítulo cuarto del praeceptum: "No sea llamativo vuestro porte, ni procuréis agradar con el modo de vestir, sino con la manera de comportaros" (4,1). Cierto, san Jerónimo habla a una mujer del comportamiento indebido de otras mujeres, mientras que san Agustín habla a hombres, pero lo importante es la coincidencia de ambos en relacionar el modo de vestir con la guarda de la castidad ${ }^{13}$.

San Jerónimo habla de gente de su propio estado "que ambicionan ser presbíteros o diáconos para poder ver más libremente a mujeres. Toda su preocupación es el vestido, andar bien perfumados y que el pie no se mueva dentro del zapato como si fuera un fuelle. Los cabellos ensortijados llevan las señales del rizador, los dedos lanzan destellos por los anillos, y para que la humedad de la calle no les moje la planta del pie, apenas si pisan el suelo con la punta de los zapatos. Cuando vieres a gentes semejantes, tenlos más bien por pretendientes que por clérigos" $(22,28)^{14}$. Datos como este pueden estar también detrás de la recomendación con que comienza el capítulo cuarto del praeceptum, indicado en el punto anterior. Es cierto que san Jerónimo habla de clérigos -"hablo sólo de los de mi propio estado", decía-, pero eso no obsta, pues lo importante aquí no es aquel de quien se predica, sino lo que se predica, a saber, el recurso a un determinado modo de vestir para llamar sobre sí la atención de las mujeres, hecho que ponía en peligro la castidad.

Tema frecuente en la carta de san Jerónimo es el de las salidas al exterior, que limita al máximo a su dirigida Eustoquia. Primero le prohíbe asistir a reuniones de las matronas, frecuentar las casas de los nobles y ver a quienes despreció por su voluntad de ser virgen (cf. 22,16). En el apartado siguiente le dice explícitamente: "Sea rara tu salida al público: busca a los mártires en tu propio aposento", a lo que añade: "Si tuvieras que salir (pro-

\footnotetext{
${ }^{13}$ Damos por hecho que en el capítulo cuarto del praeceptum san Agustín piensa, desde el primero hasta el último parágrafo, en la castidad.

${ }^{14}$ Cf. A. CAIN, The letters of Jerome, p. 89.
} 
cedere) siempre que es menester, nunca te faltarían pretextos para salir (procedere) $(22,17)$. Más adelante vuelve sobre el mismo pensamiento: "Te conjuro, pues, delante de Dios y de Cristo Jesús... que no seas ligera en mostrar al público los vasos del templo, que sólo a los sacerdotes es concedido ver. Que ningún profano mire el sagrario de Dios... Pues ningún vaso de oro o de plata fue tan querido de Dios como el templo de un cuerpo virginal" $(22,23)$. Por último, dos apartados más adelante, le dice: "Procura no salir de tu aposento para ir a casa; no vayas a ver a las hijas de una región extraña teniendo tú por hermanos a los patriarcas y pudiéndote gloriar de tu padre Israel. Dina fue violada por salir de casa. No quiero que busques a tu esposo por las plazas ni que recorras los rincones de la ciudad... Al esposo no se le puede encontrar por las plazas" $(22,25)$. También el autor del praeceptum se interesa por las salidas de sus religiosos, respecto de las cuales tiene su palabra que decir: "Cuando salgáis (proceditis), id juntos; cuando lleguéis a donde os dirigís, permaneced juntos" $(4,2)$. El hecho es el mismo -las salidas-y el mismo el interés que mueve a ambos autores a hablar de él: la protección y salvaguarda de la castidad. Pero es distinta la actitud que uno y otro toman ante el hecho. San Jerónimo pone restricciones, san Agustín da orientaciones sin poner límites a las salidas. Obviamente, se trataba de situaciones distintas.

San Jerónimo critica también a los clérigos que andaban de casa en casa de las matronas romanas. "Algunos consumen sus vidas en conocer los nombres, las casas y las costumbres de las matronas". De ellos pinta breve y someramente uno sólo -el rey en ese arte-, "para que, conocido el maestro, reconozcas más fácilmente a los discípulos". De él dice, entre otras cosas, que se mete casi en las alcobas de las que están durmiendo, y que sus enemigos son tanto la castidad como los ayunos (cf. 22,28). Comportamientos como este cabe que estén detrás de lo prescrito en el praeceptum sobre las salidas, ya indicado en el apartado anterior. En efecto, al salir juntos, a los religiosos se les vuelve difícil, si no imposible, imitar las actividades del clérigo que acaba de describir y que significan un grave riesgo para la castidad. Como en el caso anterior, carece de mayor importancia que san Jerónimo se refiera a clérigos y san Agustín a monjes. Lo importante es la indicación de que el salir solo favorece el frecuentar mujeres y pone en peligro la castidad. San Jerónimo describe un comportamiento peligroso para esa virtud, san Agustín indica cómo han de proceder los monjes para que no llegue a darse.

A la hora de caracterizar a las vírgenes que han sucumbido, san Jerónimo no se queda corto. Después de indicar que para ellas el ayuno es una herejía, añade: "Estas son las que se hacen notar en público y con guiños furtivos arrastran en pos de sí a toda una grey de jovenzuelos. Estas son las que 
deberían oír permanentemente de boca del profeta: Tienes rostro de mujer descarada y no te avergüenzas ( $\mathrm{Jr} 3,3)$... el caminar es lánguido debido al movimiento desenvuelto de las rodillas" (22,13). Este dato puede estar presente en la mente de Agustín cuando, invitando a los monjes a un comportamiento conforme a su propia condición, escribe: " $\mathrm{Al}$ andar, al estar parados y en todos vuestros movimientos, nada hagáis que sirva de escándalo a la mirada de otra persona" $(4,3)$. En efecto, también los religiosos podían hacer gestos para llamar la atención y arrastrar tras de sí a mujeres. Pero puede estar también detrás de la recomendación inmediatamente siguiente: "Cuado dirijáis vuestros ojos hacia alguna mujer, no los dejéis prendidos en ninguna" $(4,4)$. En efecto, el santo podía estar pensando en mujeres descaradas y provocadoras de que habla el texto profético citado por san Jerónimo.

San Jerónimo se pregunta que sucederá a las vírgenes que prostituyeron los miembros de Cristo y convirtieron el templo del Espíritu Santo en lupanar, si las hubo que se condenaron a pesar de ser vírgenes, reas de otras culpas $(22,6)$. Reminiscencias de esta idea se pueden percibir en el capítulo cuarto del praeceptum. Es el caso cuando recomienda a los religiosos que no hagan otra cosa "sino lo que se ajuste a vuestra santidad" $(4,3)$. Leída esta recomendación en el contexto de la castidad de que habla el capítulo y del parágrafo en que se encuentra, parece lógico referirla a la santidad del cuerpo del cristiano, templo del Espíritu santo, como proclama san Pablo en 1 Cor 3,17 (Si alguno destruye el templo de Dios, Dios lo destruirá a él porque el templo de Dios es santo, y vosotros sois ese santuario). Según san Jerónimo, si algunas vírgenes se han condenado por culpas de otra naturaleza, cabe suponer una condena mayor para las que convirtieron el templo del Espíritu en un lupanar. En esa misma línea, la recomendación de san Agustín de hacer sólo lo que se ajuste a la propia santidad, es decir, a la santidad del propio cuerpo, templo de Dios, va orientada a evitar la destrucción -condena- de que habla san Pablo. También cabe interpretar en ese contexto y sentido lo afirmado más adelante en el mismo capítulo del praeceptum: "Pero no causáis menor daño a vuestros hermanos, a los que podéis hacer que se corrijan señalándolos, si por callar, permitís que perezcan" $(4,8)$. Se puede entender que el silenciar la falta contra la castidad de un hermano puede llevar a su destrucción -perire-, el castigo para quien profane el templo de Dios.

San Jerónimo habla de la perdida de la virginidad que acontece en el interior (mente), aun sin perderla a un nivel físico. Como prueba de que puede darse, cita Mt 5,28: Quien mire a una mujer deseándola ya adulteró con ella en su corazón $(22,5)$. Ahora bien, respecto a lo primero, san Agustín contempla explícitamente el hecho de la pérdida de la virginidad: "la castidad 
misma huye de las costumbres, aunque la violación impura no llegue a tocar los cuerpos" $(4,4)$. Además de eso, en el mismo parágrafo el santo habla del corazón (animus) impuro de que es prueba la mirada impura $(4,4)$. Como en san Jerónimo, el adulterio del corazón es puesto en relación con la mirada (qui uiderit). Respecto a lo segundo, los autores suelen presentar el mismo texto de Mt 5,28 como base bíblica de la afirmación agustiniana.

Escribe san Jerónimo a Eustoquia: "Tú hablas con sencillez (sin mala intención) y, delicada como eres, no rechazas a los desconocidos; pero los ojos impúdicos miran de otra manera. No saben ver la belleza del alma, sino la del cuerpo" (22,23). Esto nos remite a las siguientes palabras del praeceptum: "No digáis que es puro vuestro interior (uos animos habere pudicos) si tenéis ojos impuros (oculos impudicos), puesto que el ojo impuro es mensajero de un corazón impuro" $(4,4)$. La coincidencia, esta vez hasta en los términos latinos empleados, está en los "ojos impuros".

Para mostrar cómo la falta de control de la vista constituye un grave peligro para la castidad, san Jerónimo recurre al ejemplo de David quien, aunque fue elegido por ser conforme al corazón del Señor y cantó a menudo la futura venida de Cristo, por ver caminar sobre la terraza de su casa a Betsabé desnuda, acabó convirtiéndose en adúltero y homicida. Y comenta: "Advierte de paso cómo no hay mirada segura, ni siquiera en casa" $(22,12)$. El ejemplo y la moraleja que saca san Jerónimo bien puede estar en el trasfondo de lo que dice san Agustín sobre la mirada en relación con la violación de la castidad: "Y tanto el querer que os deseen mujeres como el desearlas vosotros, no lo suscita sólo el tacto y el afecto, sino también la mirada" $(4,4)^{15}$.

San Jerónimo invita a Eustoquia a gritar que el Señor es su ayuda (cf. Sal 117,6) "tan pronto como el suave incendio del placer nos invada con agradable calor" $(22,6)^{16}$, palabras que traen a la mente estas otras del praeceptum: "y, como sucede en el deseo carnal, hallan deleite en el ardor recíproco" $(4,4)$. Los dos textos coinciden en la idea de ardor/calor vinculado al placer sexual, aunque san Jerónimo habla en general, mientras que san Agustín se refiera al efecto del deseo y de la mirada mutua en aquellos en cuyos corazones anida la lujuria.

San Jerónimo aconseja a Eustoquia: "No permitas que tus pensamientos ganen terreno; que nada babilónico, nada confuso prospere en ti. Mientras el enemigo es pequeño, degüéllalo; la maldad hay que extirparla en ger-

\footnotetext{
${ }^{15}$ Refiriéndose al deseo de David respecto de Betsabé, Agustín utiliza el término petulantia, el mismo utilizado en el Praeceptum (4,7) (cf. en. Ps. 50,3).

${ }^{16}$ La metáfora del fuego para describir las pasiones aparece también en 22,7,2 y 22,8,2.
} 
men" (22,6, citando Sal 136,8-9). Estc mismo pensamiento se halla también en estas palabras del praeceptum: "Y si advirtierais en alguno de vosotros esa mirada lujuriosa de que os hablo, amonestadle sobre la marcha para que el mal ya manifestado no vaya a más, sino que se corrija de inmediato" $(4,7)$. La coincidencia está en el consejo de dar muerte al vicio, en ambos casos el de la lujuria, tan pronto como se manifieste; la divergencia está en que san Jerónimo habla de pensamientos, mientras san Agustín se refiere específicamente a la mirada ${ }^{17}$.

Después de haber relatado el castigo infligido al monje que al morir dejó amasada una cantidad de dinero, es decir, el enterrar el dinero con él, como fruto de una "traición", el monje dálmata añade un comentario: "Nadie piense que se hizo esto por crueldad; pero fue tal el terror que cundió por todo Egipto, que ahora se considera crimen haber dejado un solo sólido" $(22,33)$. La misma idea de que una sanción dura no significa crueldad para con quien la recibe aparece claramente en el praeceptum agustiniano: "En efecto, si tu hermano tuviese una herida corporal que quisiera ocultar por temor a la cura, ¿no sería cruel silenciarla y misericordioso darla a conocer? ¡Cuánto más, entonces, debes descubrirle a él para que la podredumbre no invada, con mayor daño, su corazón!" $(4,8)$. Y en el parágrafo siguiente: "Pues tampoco esto se hace por crueldad, sino por misericordia, para evitar que con su pestífero contagio lleva a la perdición a otros muchos" $(4,9)$. Es obvio que se trata de faltas distintas: en san Jerónimo, la de haber acumulado dinero; en Agustín, la de haber sucumbido a la mirada lujuriosa y no querer reconocerlo, pero la idea es la misma: la sanción no la impone la crueldad, sino -añade las dos veces san Agustín, complementando la idea de san Jerónimo- la misericordia. Pero hay todavía otro particular que merece ser puesto en luz: en ambos autores, la justificación del castigo -y por eso no ha de verse como acto de crueldad-va asociado a un amplio efecto social, pero de distinta naturaleza y signo. San Jerónimo lo señala como hecho real: "fue tal el terror que cundió por todo Egipto, que ahora se considera crimen haber dejado un solo sólido"; san Agustín, por el contrario, piensa en evitar que el mal se extienda, en el primer caso, al corazón entero del religioso -“invada, con mayor daño, su corazón”- y , en el segundo caso, a la comunidad entera -"para evitar que con su contagio pestífero lleve a la perdición a otros muchos"-. La dureza tiene valor por su eficacia social: en el caso de san Jerónimo, ejemplarizante; en el de san Agustín, de prevención.

17 Un poco más adelante, repite la misma idea: “... es proclamado bienaventurado aquel que apenas empieza a pensar degüella y quebranta los pensamientos sobre la peña" $(22,6)$. El contexto no deja duda de que se trata de pensamientos lujuriosos. 
San Jerónimo habla de las muchas vírgenes que quebrantan a diario su propósito de virginidad, de las muchas que de su seno pierde cada día la madre Iglesia (cf. 12,13). El praeceptum no afirma nada al respecto de forma explícita, pero, de una parte, lo deja entrever cuando ordena la expulsión del que no acepta la sanción expuesta, "para evitar que con su contagio pestífero lleve a la perdición a otros muchos" $(4,9)$; de otra, todo el capítulo cuarto presupone esa realidad para evitar la cual propone un actuar preventivo y curativo.

\section{e) Capítulo quinto del praeceptum}

A continuación, san Jerónimo alude también a muchas vírgenes que, teniendo los armarios llenos de ropa, no pueden acabar con la polilla $(22,32)$. Significativamente también san Agustín habla de la polilla en el parágrafo primero del capítulo quinto, en que ordena poner toda la ropa en común "bajo la custodia de uno, de dos o de cuantos puedan bastar para sacudirla, a fin de que la polilla no la dañe" $(5,1)$. La coincidencia entre los dos textos está sólo en la mención de la polilla, mención que tiene una función distinta en cada caso: en san Jerónimo el hecho de que pueda dañar la ropa se convierte en invitación a desprenderse de ella, en san Agustín en invitación a ponerla en común. Antes de que la polilla dañe la ropa hay que darla a los pobres, piensa san Jerónimo; para evitar que se apolille, hay que ponerla en común al cuidado de cuantas personas sean necesarias, dice san Agustín. Es cierto que el evangelio habla de la polilla como agente corruptor de los tesoros (cf. Mt 6,19-20; Lc 12,33), pero no deja de llamar la atención esta coincidencia en asociar la polilla a los vestidos, si se tiene en cuenta que, fuera del praeceptum, en el resto de su amplia obra sólo lo hace una vez y de forma marginal $^{18}$.

Según san Jerónimo, en los cenobios a nadie le era lícito decir: "No tengo túnica ni capa ni jergón de juncos". Como razón aduce que el mayordomo "lo dispone todo de manera que nadie tenga que pedir nada ni a nadie le falte nada" $(22,35)$. Un eco de esta realidad lo encontramos también en una recomendación del capítulo quinto del texto agustiniano: "Si es posible, no sea incumbencia vuestra determinar la ropa que habéis de llevar según las circunstancias... siempre que a nadie se le niegue lo que necesite" $(5,1)$. En el capítulo primero, el legislador de Hipona ya había determinado que el encargado de distribuir la ropa (y el alimento) era el prepósito

\footnotetext{
${ }^{18}$ Cf. s. 149,9 .
} 
$(1,3)$. La idea es común, con dos datos: que el religioso ha de despreocuparse de la ropa que debe llevar y que alguien del monasterio se encargará de prevenir que a nadie le falte nada; la diferencia está en la persona que tiene confiada esa tarea: en el cenobio cuyos usos describe san Jerónimo, el mayordomo; en el monasterio destinatario del praeceptum, el prepósito. Importante es también la coincidencia en señalar que a nadie le falta o que a nadie ha de faltarle nada que necesite ${ }^{19}$.

San Jerónimo recomienda a Eustoquia: "También has de evitar el mal de la avaricia, no en el sentido de no codiciar los bienes ajenos..., sino en de no guardar los tuyos, que son también ajenos" $(22,31)$. Este pensamiento tiene su correlato en el praeceptum en los primeros tres capítulos del capítulo quinto en el que invita a los religiosos a poner en común la ropa: "Tened vuestra ropa en común" $(5,1)$, el fruto del propio trabajo: "nadie tenga ninguna actividad puramente personal, sino que todas vuestras obras las hagáis para el bien común con mayor esmero y más renovada disponibilidad que si cada uno realizase las tareas propias para sí mismo" $(5,2)$ y hasta los regalos recibidos: "De donde se deduce que si alguien llevase algo... incluso si es a sus hijos o a otras personas... residentes en el monasterio, estos no lo reciban a escondidas; antes bien, quede en poder del prepósito para que, integrado en el fondo común, lo dé a quien tuviere necesidad de ello" $(5,3)$. La dificultad a la hora de cumplir lo mandado es, no obstante, distinta: en san Jerónimo es la incertidumbre del futuro ("Soy una joven delicada que no puedo trabajar con mis manos; cuando llegue a la vejez o me ponga enferma, ¿quién tendrá lástima de mí?" [22,31]); en san Agustín, el mantener la propia categoría social ("piensa que no se ajusta a su condición vestir como vestía su hermano" [5,1]). Una diferencia sustancial es que san Jerónimo piensa en que comparta sus bienes con los pobres ("y entre tanto Cristo está muriendo desnudo a sus puertas" [22,32]), mientras que san Agustín habla de compartirlos con los hermanos de comunidad ${ }^{20}$.

San Jerónimo cuenta el caso de aquel monje que al morir dejó cien sólidos, que había ganado tejiendo lino; refiere también la diversidad de pareceres sobre lo que había que hacer con ellos: si repartirlos entre los pobres, donarlos a la Iglesia o remitirlos a sus padres, y la decisión tomada, bajo la inspiración del Espíritu santo, por los llamados "padres": enterrarlos

\footnotetext{
${ }^{19}$ San Jerónimo añade además que "nadie tenga que pedir nada".

${ }^{20}$ Sabido es que en la regula recepta el parágrafo tercero del capítulo quinto concluye con una calificación moral de quien se comporta diversamente: "Si alguien oculta algo que le han llevado, sea condenado como reo de hurto" $(5,3)$. Cabe preguntarse si el autor de este añadido no habría intentado introducir así en el Praeceptum la razón aducida por san Jerónimo: "que son también ajenos".
} 
con su dueño, "pues dijeron: Tu dinero sea contigo para perdición (Hch $8,20)$ " (22,33). Con estas palabras los "padres" reprobaban el haber acumulado dinero, en lugar de haberlo compartido con otros. La misma idea puede estar en la afirmación de san Agustín de que cada uno debe trabajar para el bien común con mayor esmero y más renovada disponibilidad que si cada cual realizase las tareas propias para sí mismo $(5,2)$, o cuando afirma que el termómetro para medir el progreso espiritual está en cuidar de lo común mejor que de lo propio $(5,2)$. Uno y otro autor negocian con la misma moneda, sólo que san Jerónimo se fija en la cruz, mientras san Agustín contempla la cara.

San Jerónimo escribe a su dirigida: "El vestido, ni limpio en exceso ni tampoco sucio, y no llame la atención por nada, para que la gente no se pare delante de ti y te señale con el dedo" $(22,27)$. Esto nos lleva a la recomendación que hace san Agustín en el capítulo quinto del praeceptum: "El lavado de la ropa, realizado por vosotros mismos o por lavanderos, hágase conforme al criterio del prepósito para evitar que el afán excesivo de llevar la ropa limpia arrastre consigo manchas interiores en el alma" $(5,4)$. Ambos textos hacen referencia a una excesiva preocupación por la limpieza de la ropa que se lleva puesta, indicando la razón por la que debe evitarse: san Jerónimo para evitar que los demás se fijen en quien la lleva, san Agustín para evitar manchas en el alma, sin especificar cuáles son. Quizá estemos ante la misma realidad, contemplada desde dos ángulos diversos: san Jerónimo atiende a la reacción de los demás, san Agustín a la respuesta a la reacción de los demás: la complacencia vanidosa ante el hecho de ser objeto de atención.

El cenobio descrito por san Jerónimo no descuida a los enfermos: " $\mathrm{Si}$ alguno se pone enfermo, se le traslada a una sala más amplia, donde es atendido por los viejos con tan solícito cuidado que no echa de menos las comodidades de la ciudad ni el cariño de la propia madre" $(22,35)$. También san Agustín trata en el mismo capítulo quinto de la atención a los enfermos: "El cuidado de los enfermos, o de los convalecientes, o de quienes, aun sin tener fiebre, padecen algún achaque, debe confiarse a alguien para que personalmente pida de la despensa lo que advierta que cada uno de ellos necesita" $(5,8)$. Uno y otro texto tienen en común el señalar que hay encargados para atender a los enfermos y el hecho o la exigencia de una atención esmerada; en los demás puntos, son muy divergentes. Ciertamente esta coincidencia tiene poco peso por la naturaleza del servicio que propone. 


\section{f) Capítulo sexto del praeceptum}

Según san Jerónimo, "es difícil que el alma humana no ame, e ineludiblemente nuestro espíritu es arrastrado por algún amor. El amor de la carne se vence por el amor del espíritu, y un deseo se vence con otro deseo. Lo que el uno disminuye, el otro crece. Lo mejor que puedes hacer es repetir constantemente: En mi lecho, por las noches, he buscado al amor de mi alma (Cant 3,1)" (22,17). Estos pensamientos de san Jerónimo pueden dar razón de otro presente en el praeceptum: "Vuestro amor no ha de ser carnal, sino espiritual" $(6,3)$, palabras con que concluye el capítulo.

\section{g) Capítulo octavo del praeceptum}

San Jerónimo pone fin a su exhortación a Eustoquia con el reclamo del amor: "Todo lo dicho hasta aquí parecerá duro a quien no ame a Cristo. Pero quien tenga por basura toda la pompa del siglo y juzgue vanidad todo lo que hay bajo el sol a cambio de ganar a Cristo, quien ha muerto con su Señor y ha resucitado con Él, y quien ha crucificado su carne con todos sus vicios y concupiscencias, este proclamará libremente: ¿Quién nos separará del amor de Cristo?... (Rom 8,35-39)" (22,39). Y en el apartado siguiente: "Para los que aman no hay nada duro, y para quien desea algo no hay trabajo dificultoso. Mira lo que aguanta Job por Raquel, que le fue prometida por mujer (cf. Gén 29,30)... Amemos también nosotros a Cristo, busquemos sus caricias, y todo lo difícil se nos hará fácil. Nos parecerá breve todo lo que es largo y, heridos por su dardo, diremos a cada momento: ;Ay de mí, que se ha prolongado mi peregrinación! (Sal 119,5)" $(22,40)$. Ahora sólo cabe mirar al último capítulo del praeceptum: "Que el Señor os conceda cumplir todos estos preceptos con amor" $(8,1 \mathrm{a})$. Además, en el tener por basura la pompa del siglo y juzgar vanidad todo lo que hay bajo el sol puede estar recogido el contenido de los capítulos quinto, sexto y séptimo del praeceptum, y en el crucificar su carne con todos sus vicios y concupiscencias, el contenido de los capítulos tercero y cuarto. Pero más allá de la fórmula concreta utilizada por uno y otro autor en el primer caso y de los contenidos comunes, en el segundo, está el hecho de que, al final de sus respectivos textos, ambos maestros de vida espiritual introducen el amor al que asignan idéntica función: hacer posible el cumplimiento de todo lo indicado con anterioridad. Pero no todo acaba aquí. Si san Jerónimo alude específicamente al amor a Jesucristo, san Agustín sigue sus huellas cuando presenta a los monjes como "enardecidos por el buen olor de Cristo" (8,1c). Un "enardecidos" que implica un 
deseo ardiente, ansia de alcanzar a Cristo cuyo buen olor seduce; deseo que, por otra parte, hace sentir largo el tiempo de espera. Pero procede señalar una diferencia significativa: san Jerónimo no dice nada sobre la fuente de ese amor; para san Agustín esa fuente es Dios.

San Jerónimo pone término a su tratado con estas palabras: "Siempre que la vana ambición del siglo te halague, siempre que veas el fasto del mundo, trasládate en espíritu al paraíso. Empieza a ser lo que serás un día, y así podrás oír a tu esposo: "Ponme cual sello en tu corazón, como un sello en tu brazo (Ct 8,6). Fortalecida en tus actos y en tu espíritu gritarás: Grandes aguas no pueden apagar el amor, ni los ríos anegarlo (Ct 8,7)" $(22,41)$. A lo que hay que añadir lo escrito poco antes: "Entonces el esposo mismo te saldrá a recibir y te dirá: Levántate, amada mía, hermosa mía, paloma mía, y vente. Porque, mira, ha pasado ya el invierno y la lluvia se ha ido (Ct 2,10$11)$ " $(22,41)$. Dos son las ideas que hay que resaltar de este texto: una, la mirada escatológica; otra, el recurso a textos del Cantar de los cantares ${ }^{21}$. Y ahora, cabe la pregunta: ¿no tendremos ambas cosas también en el praeceptum? Sólo hace falta ver en el "enardecidos por el buen olor de Cristo" $(8,1 c)$ una paráfrasis de Ct 1,3: Correremos tras el olor de tus perfumes ${ }^{22}$.

En su carta san Jerónimo cuenta cómo, en medio de la mayor austeridad, su imaginación se hallaba a menudo ocupada con imágenes de muchachas danzando y cómo, aunque su rostro estaba pálido por los ayunos, su alma ardía de pasión dentro de su cuerpo helado. En ella sólo hervían sus apetitos. En esos momentos, cual nueva mujer pecadora, él se arrojaba a los pies de Jesús, los regaba con sus lágrimas, los enjugaba con sus cabellos (cf. Lc 7,38) y domaba su carne con ayunos que duraban semanas. Tras describir sus ejercicios ascéticos, concluye: «Y el Señor mismo me es testigo de que, después de muchas lágrimas, después de estar con los ojos clavados en el cielo, me parecía hallarme en medio de los ejércitos angélicos; entonces cantaba con alegría y regocijo: En pos de ti corremos al olor de tus perfumes $(\mathrm{Ct}$ $1,3) »(22,7)$. El texto invita a hacer dos observaciones. La primera, que en él aparecen asociados la lujuria y el perfume, al haber ungido con él los pies de Jesús la mujer pecadora con que se identifica Jerónimo. La segunda, que el deseo de mujeres (dato negativo) del monje Jerónimo y sus ayunos (dato positivo) le llevan a sentirse corriendo en pos de Cristo al olor de sus perfumes (Ct 1,3). Si ahora nos fijamos en el praeceptum advertimos que en el

\footnotetext{
${ }^{21}$ Sobre la orientación escatológica del monacato antiguo según la carta jeronimiana, cf. R. BYRnE, The Cenobitic Life, pp. 284-285.

${ }^{22}$ Tal es la interpretación que hemos dado en nuestro artículo: Comentario a la Regla de san Agustín. Capítulo octavo (III/B), en Estudio Agustiniano 43 (2008) 517-542.
} 
capítulo tercero habla del ayuno $(3,1)$; en el cuarto, del deseo de mujeres $(4,4)$, y en el octavo, del buen olor de Cristo $(8,1 \mathrm{c})$. La comparación se puede establecer en estos términos: al tema del ayuno (cap. $3^{\circ}$ ) y al del deseo de mujeres (cap. $4^{\circ}$ ) va asociado el deseo ardiente del buen olor de Cristo (cap. $\left.8^{\circ}, 1 \mathrm{c}\right)^{22}$. Por supuesto hay diferencias entre ambos textos: una, el orden en que se habla de los temas; san Jerónimo habla primero del deseo de mujeres, y luego de los ayunos; san Agustín, primero del ayuno y luego del deseo de mujeres; otra, en san Jerónimo el ayuno aparece como remedio contra el deseo de mujeres, relación que san Agustín no establece; una tercera, que san Jerónimo cita de forma explícita Ct 1,3, mientras que san Agustín habla simplemente del deseo ardiente del buen olor de Cristo, expresión que puede entender -repetimos- como paráfrasis de $\mathrm{Ct}$ 1,3.

\section{Las coincidencias}

En 31 textos de la carta de san Jerónimo hemos hallado coincidencias, de relieve desigual, con otros textos del praeceptum, que permiten suponer que san Agustín encontró en ella inspiración para su escrito. Los textos aducidos son de dos clases: en unos, los más, se ha constatado una coincidencia de contenidos; en otros, los menos, algunos datos que pueden dar razón de lo que el legislador de Hipona prescribe.

Hablamos de coincidencia de contenidos cuando en los dos escritos aparece un mismo tema, independientemente de cómo esté expresado, fundamentado y aplicado. A continuación enumeramos cuáles son los temas comunes a la carta y al praeceptum, indicando el número del elenco anterior en que el lector puede hallar los textos respectivos. Helos aquí:

- Enorgullecerse de la propia categoría social, presumir de las propias riquezas, despreciar a los demás: en $\mathrm{n}^{\circ} 1^{\circ}$.

- Una acción laudable puede engendrar orgullo y el orgullo destruye la bondad de la acción laudable: en $\mathbf{n}^{\circ} 2$.

- Poner en común una parte de los propios haberes: en $n^{\circ} 3^{\circ}$.

- Vida de oración conforme a la enseñanza paulina y distribución a lo largo de la jornada de momentos específicos dedicados a ella: en $n^{\circ} 4^{\circ}$.

- La oración como ocupación del monje en el tiempo que le quede libre, una vez concluido el trabajo que le ha sido asignado: en $\mathrm{n}^{\circ} 5^{\circ}$.

- Trato de privilegio, en el menú y en el horario, a dos grupos de personas de riesgo: en $n^{\circ} 6^{\circ}$.

- Ruido en el refectorio durante la comida: en $n^{\circ} 7^{\circ}$. 
- Un determinado modo de vida anterior que dificulta seguir un régimen de vida austero: en $n^{\circ} 8^{\circ}$.

- Salidas al exterior: en $n^{\circ} 11^{\circ}$.

- Comportamientos que miran a seducir a la persona del sexo opuesto: en $\mathrm{n}^{\circ} 13^{\circ}$.

- Pérdida de la castidad del corazón sin pérdida física de la misma: en $\mathrm{n}^{\circ} 15^{\circ}$.

- Los ojos impuros: en $n^{\circ} 17^{\circ}$.

- La mirada en relación con la pérdida de la castidad: en $\mathrm{n}^{\circ} 17^{\circ}$.

- El ardor asociado a la pasión impura: en $n^{\circ} 18^{\circ}$.

- Atajar el mal de la lujuria nada más manifestarse: en $n^{\circ} 19^{\circ}$.

- Sancionar una falta no implica crueldad: en $\mathrm{n}^{\circ} 20^{\circ}$.

- La polilla que puede dañar la ropa: en $n^{\circ} 22^{\circ}$.

- No es el monje el que determina qué ropa ha de ponerse: en $n^{\circ} 23^{\circ}$.

- Compartir los bienes: en $\mathrm{n}^{\circ} 24^{\circ}$.

- No trabajar para uno mismo: en $\mathrm{n}^{\circ} 26^{\circ}$.

- Excesivo afán por llevar la ropa limpia: en $n^{\circ} 26^{\circ}$.

- Debida atención a los enfermos: en $\mathrm{n}^{\circ} 27^{\circ}$.

- El amor carnal contrapuesto al amor espiritual: en $n^{\circ} 28^{\circ}$.

- El amor, condición para cumplir los preceptos: en $\mathrm{n}^{\circ} 29^{\circ}$.

- Tensión escatológica: en $\mathrm{n}^{\circ} 30^{\circ}$.

- El olor de los perfumes de Cristo: en $n^{\circ} 31^{\circ}$.

En la mayor parte de los casos la coincidencia se da en el tema tratado, no en los términos en que se expresa. De hecho son pocas las coincidencias verbales que se pueden señalar con valor en nuestro contexto. Una, en los textos señalados en el $\mathrm{n}^{\circ}$ 17: ambos autores hablan de los "ojos impuros" (impudici oculi/oculos impudicos); otra, en el n ${ }^{\circ} 21$ : ambos textos contienen el verbo fieri (factum/fit), el demostrativo hoc, un adverbio de negación nec/non y el adverbio crudeliter, expresando la misma idea: sancionar una falta "no se hace por crueldad" (Nec hoc crudeliter quisquam factum putet / Non enim et hoc fit crudeliter $)^{23}$. Una tercera, en los textos del $\mathrm{n}^{\circ} 28$ que mencionan ambos en amor carnal y el espiritual (carnis amor/spiritus amore - carnalis [dilectio] /spiritalis dilectio), aún con sus diferencias ${ }^{24}$,

${ }^{23}$ Todavía cabe añadir una referencia escatológica en las palabras: "me parecía hallarme en medio de los ejércitos angélicos", que posiblemente remiten a Mt 22,30 ("Pues en la resurrección ni ellos tomarán mujer ni ellas marido, sino que serán como ángeles en el cielo»).

${ }^{24}$ De hecho, esta es la única referencia del Praeceptum a la Carta 22 de san Jerónimo que señala A. de Vogüé (cf. Histoire littéraire, III, p. 191). 
Además de los numerosos puntos de coincidencia señalados, merecen atención dos datos. El primero se refiere a la desproporcionada extensión que el tema de la castidad tiene en el praeceptum, comparado con otros temas también importantes, el más significativo de los cuales puede ser el de la oración. El capítulo cuarto del praeceptum tiene una extensión equivalente a casi un cuarto del conjunto del texto monástico. El hecho ha llamado la atención de los estudiosos ${ }^{25}$. Para explicar esa desproporción es frecuente acudir a la historia personal de su autor, específicamente a sus problemas de castidad en el período previo a su conversión, de que dejó tan clara constancia en las Confesiones. Pero quizá halle explicación mejor aceptando una amplia inspiración en el texto jeronimiano. Al tratar preferentemente sobre la castidad, es lógico que le aportara más material para el capítulo cuarto que para otros capítulos. El segundo dato guarda relación con la repetida afirmación de san Jerónimo de que en su carta no se propuso como objetivo cantar las glorias de la virginidad. En un primer pasaje, porque las presupone bien conocidas por Eustoquia que ya la había aceptado como norma de vida $(22,2)$. En otro pasaje, porque esa loa ya lo habían cantado otros autores como Tertuliano, san Cipriano, san Dámaso o san Ambrosio (22,22). Marcando distancias con el tratado de san Ambrosio sobre las vírgenes, escribe: "Nosotros seguimos otro enfoque: no exaltamos la virginidad, sino que la guardamos. No basta con saber lo que es bueno si no se observa con toda diligencia lo que ya se ha escogido. Lo uno es cosa de especulación, lo otro de esfuerzo; aquello es común a muchos, esto a pocos" $(22,23)$. Ahora bien, en el praeceptum encontramos esa misma realidad, aunque sin una declaración explícita de intenciones semejante a las de san Jerónimo. Tampoco al obispo de Hipona le interesan los planteamientos teóricos sobre la castidad, sino el modo de conservarla. Esa falta de teología es algo que también ha llamado la atención de más de un comentarista del texto agustinano ${ }^{26}$. También a este respecto se han dado diversas explicaciones, pero quizá la

${ }^{25}$ Los dos autores utilizan un término diferente para designar al amor (dilectio/amor); asimismo, para especificar el amor, san Jerónimo se sirve del complemento del nombre (carnis/spiritus) y san Agustín del adjetivo (carnalis/spiritalis).

${ }^{26} \mathrm{Cf}$. L. VERHEIJEN, Le très difficile quatrième chapitre. Le célibat monastique et la sollicitude pour les pécheurs», en Augustiniana 29 (1979) 43-86:44-45; A. ZUMKELlER, The Rule of Saint Augustin with a Commentary, Wisconsin 1961, p. 83; AGATHA MARY, The Rule of Saint Augustin. An Essay in Understanding, Augustinian Press, Villanova 1992, p. 145; ID., Looking at the Rule of saint Augustine, en Augustinian Heritage 38 [1992] 23-36:30;C. BoFF: El camino de la comunión de bienes, Bogotá 1991, p. 103;. L. Cilleruelo, Comentario a la Regla de san Agustín, Valladolid 1994, p. 341; MARIE-ANCILLA, OP, La Règle de saint Augustin, Paris 1996, p. 215 . 
más fácil y convincente sea aceptar que el obispo de Hipona seguía la pauta marcada por el monje Jerónimo en la carta que nos ocupa.

Más allá de la coincidencia en el contenido, hay que asignar también valor a la ubicación de determinados temas en uno y otro escrito. A este respecto es significativo este dato: ambos autores concluyen sus respectivos escritos con una referencia al amor como la condición que posibilita el cumplimiento de lo preceptuado anteriormente, y una referencia escatológica, que se inspira en textos del Cantar de los Cantares. La referencia al amor está recogida en el n 29: si san Jerónimo escribe a Eustoquia que, para los que aman, nada hay duro ni dificultoso, san Agustín expresa su deseo de que Dios conceda al monje cumplir todo con amor, es decir, por medio del amor. La referencia escatológica, en el $\mathbf{n}^{\mathbf{0}}$ 30: san Jerónimo invita a Eustoquia a pensar en el momento en que el Esposo salga a recibirla; san Agustín presenta al monje anhelando ese momento ("enardecidos por el buen olor de Cristo").

Como ya indicamos, entre los textos jeronimianos recogidos en la primera sección hay algunos que propiamente no contienen coincidencias con otros del praeceptum, pero que aportan datos sobre la vida de monjes, vírgenes e incluso clérigos que pueden dar razón de algunas disposiciones presentes en el texto agustiniano. Se trata de datos relativos a comportamientos que se desviaban del ideal de la virginidad o castidad consagrada. El caso lo encontramos en los $\mathrm{n}^{\circ \mathrm{s}} \mathrm{del} 10^{\circ}$ al $13^{\circ}$. Los textos de la carta recogidos en $\operatorname{los} \mathrm{n}^{\mathrm{os}} 10^{\circ}$ y $11^{\circ}$ aluden a la utilización del modo de vestir como arma al servicio de la seducción de personas del sexo opuesto ${ }^{27}$. Nos parece que no cae fuera de la lógica pensar que la inspiración para la recomendación con que san Agustín comienza el capítulo cuarto del praeceptum ("No sea llamativo vuestro porte, ni pretendáis agradar con el modo de vestir, sino con la manera de comportaros"), se halle en esos datos. A su vez, los textos del monje dálmata recogidos en $\operatorname{los} \mathrm{n}^{\mathrm{os}} 12^{\circ}$ y $13^{\circ}$ refieren situaciones peligrosas para la guarda de la castidad en las salidas de casa: el texto del $\mathrm{n}^{\circ} 11^{\circ}$ habla de la violación de una virgen, y el del $\mathrm{n}^{\circ} 12^{\circ}$, de clérigos que hasta casi se meten en las alcobas de matronas que aún están durmiendo. Por ello, pensamos que tampoco es descaminado suponer que esa información pudo inspirar lo ordenado por san Agustín en el segundo parágrafo del mismo capítulo cuarto

${ }^{27}$ Cf. L. VerHeIJEN, Le très difficile, 44-45; A. ZuMKELLER: The Rule of Saint Augustin, p. 75; A. TRAPE: Sant'Agostino: La Regola, p. 145; C. BofF: El camino de la comunión de bienes, pp. 103-104. Por otra parte, igual que san Jerónimo, que, incumpliendo en parte su palabra, deja un espacio para la teología de la virginidad, también san Agustín reserva un espacio para ella al final del Praeceptum. Así hay que entender, creemos, el "enardecidos por el buen olor de Cristo". 
("Cuando salgáis, id juntos; cuando lleguéis a donde os dirigís permaneced juntos") 28 .

Otro ejemplo, menos claro, lo tenemos en los pasajes recogidos en el $n^{\circ} 15^{\circ}$. Según san Jerónimo, hay que pensar que, si se condenaron vírgenes reas de otras culpas, con más razón hay que pensar en la condenación de otras que convirtieron el templo del Espíritu Santo en lupanar. Es fácil advertir que detrás de esta reflexión se halla la afirmación paulina de que el templo de Dios es santo y que Dios destruirá a quien destruya su templo (1 Cor 3,17; cf. también 1 Cor 6,15.19). Si ello es así, no parece desatinado pensar que la referencia a ese mismo texto paulino se halle detrás de la recomendación del tercer parágrafo del capítulo cuarto del praeceptum, de hacer sólo "lo que se ajusta a vuestra santidad". Esta santidad es la santidad del cristiano en cuanto templo de Dios. Y en el contexto las palabras del santo encerrarían una velada amenaza: Dios destruirá a quien destruya (profane) su templo.

Un último ejemplo, aunque de menor grado de probabilidad, nos lo ofrecen los textos recogidos en el $\mathrm{n}^{\circ} 22^{\circ}$. San Jerónimo nos informa de que eran muchas las vírgenes que quebrantaban a diario su propósito de virginidad, muchas las que perdía cada día la madre Iglesia de su seno. Esta constatación podría estar detrás de la reflexión con la que el santo prueba que la expulsión decretada de quien no acepta el correctivo que le ha sido impuesto por la persona competente por su falta, probada, contra la castidad, es obra de misericordia: "para evitar que con su contagio pestífero lleve a la perdición a otros muchos"29.

Seguramente, ninguna de las numerosas coincidencias señaladas bastaría por sí sola para afirmar, sin dejar lugar a duda alguna, que el obispo de Hipona encontró inspiración en la carta del futuro monje betlehemita a la hora de redactar su código monástico. En principio puede haber otras explicaciones. Si hablar de una fuente literaria común de la que pudieron beber ambos autores conduce al fracaso porque no se conoce que haya existido, no está fuera de lugar pensar en otra fuente común, más genérica: la tradición ascético/monástica, que había hechos suyos bastantes de los temas antes señalados.

\footnotetext{
${ }^{28}$ En el primero, referido a monjas, escribe con ironía san Jerónimo: "Esa es toda la virginidad para ellas"; en el segundo, referido a clérigos, afirma: "Cuando vieres a gentes semejantes, tenlos más bien por pretendientes que por clérigos".

${ }^{29} \mathrm{El}$ hecho de que tanto en este caso, como en el anterior, san Jerónimo esté hablando específicamente de clérigos y no de monjes, no cambia en lo sustancial. Al contrario, puede servir como argumento a fortiori: si caen los clérigos más habituados al trato con mujeres por razones pastorales, más fácil es que caigan también los monjes.
} 
En efecto, la oración insistente y jalonada a lo largo del día se encuentra ya en Tertuliano ${ }^{30}$. La atención a los débiles de la comunidad, así como una dieta especial para grupos de personas de riesgo aparece ya en la Regla de san Pacomio, traducida por san Jerónimo ${ }^{31}$. Frente a un dormir confortable (in plumis) ya había tomado ya postura la tradición monástica ${ }^{32}$. Anteponer la guarda de la castidad a su alabanza aparece ya en san Cipriano ${ }^{33}$. La excesiva preocupación de los clérigos por vestir elegantemente debía ser algo usual, si tuvo que intervenir la jerarquía ${ }^{34}$. La cuestión de las salidas de casa era tradicional ${ }^{35}$. Del hacerse notar en público y de los guiños furtivos habían hablado ya san Cipriano y Tertuliano ${ }^{36}$. El contraponer la castidad del corazón a la simple castidad física es lugar común en la tradición patrística ${ }^{37}$. El consejo de dar muerte al vicio ya en sus comienzos, no dándole tiempo a desarrollarse, tenía ya una larga historia ${ }^{38}$. Tampoco representaba ninguna novedad la preocupación excesiva por la limpieza de la ropa ${ }^{39}$. El compartir los bienes, a imitación de la comunidad primitiva de Jerusalén (Hech 4,3235 ), era ya ideal antiguo ${ }^{40}$. La antítesis amor carnal-amor espiritual es an-

${ }^{30}$ Leyendo el Praeceptum, en algún caso se obtiene la impresión de que no sólo se separa de san Jerónimo, sino que se opone a él. La reflexión "lo que es pecado grave no es ver mujeres, sino el desearlas o querer ser deseado de ellas", podría entenderse como réplica a la crítica de san Jerónimo a quienes ambicionan el presbiterado o el diaconado para ver más libremente a las mujeres $(22,28)$. Con esto en la mente, el monje de Hipona se sintió impulsado a matizar: el pecado no está en verlas, sino en desearlas. Al dato indicado, se podría añadir todavía la recomendación de san Jerónimo a Eustoquia de dejarse ver lo menos posible: "Jesús es celoso, no quiere que otros vean tu cara. Aunque te excuses y alegues como pretexto: "Me puse el velo y me tapé la cara..." (Carta 22,25). ¿Por qué una mujer no ha de dejarse ver?

31 Cf. De orat.25: N. ADKIN, Jerome on Virginity, p. 347 (a continuación, solo ADKIN).

32 Cf. Regula Pachomii, praef. 5: AdKIN, p. 331.

${ }^{33}$ Lo habían prohibido ya Orsiesio, Basilio y Filón: ADKIN, p. 90-91.

Cf. habit. uirginum 22. La misma contraposición que establece san Jerónimo la repite más tarde Pelagio: "nobis alio magis itinere pergendum est, quibus propositum est institutionem virginis non laudem scribere" (Ad Demetriadem 1): ADKIN, p. 204-205.

${ }^{34}$ Statuta ecclesiae antiquae, p. 171,76: "clericus nec uestibus ... decorem quaerat". El mismo Sulpicio Severo describe cómo clérigos recién ordenados rehusaban vestidos de tela fina, no bastos (dial. 1,21,4): ADKIN, p. 260-261).

35 Cf. AdKIN, ad hoc, p. 135.

${ }^{36} \mathrm{Cf}$. TeRTUlliano, de cultu feminarum 2,3 y S. CYPRIANo, de habitu uirginum 9.

${ }^{37} \mathrm{Cf}$. AdKIN, p. 48-49.210. Por otra parte, no es sino una referencia a 1 Cor 7,34.

38 Cf. Orígenes, Cant. 3; hom. in Num. 2,2; 20,2; hom. in Josue 15,3; frag. in Hier. 26; ARnobio el Joven, in Ps 136,1; HilARIo, in ps. 136,14; PAULINO DE NOLA, ep. 44,3.

${ }^{39} \mathrm{Cf}$. Tertulliano, de cultu feminarum 2,5; AmBrosio, de officiis 1,19,83: ADKIn, p. 245.

40 Cf. P. C. BoRI, Chiesa primitiva. L'immagine della comunità delle origini-Atti 2,42-47; 4,32-37- nella storia della chiesa antica, Brescia 1974, pp. 152-178; T. vAN BAVEL, Carisma: Comunidad. La comunidad como lugar para el Señor, Religión y cultura, Madrid 2004. Cap. I: La comunidad de Jerusalén y la historia de la vida religiosa, pp. 17-49. 
terior a san Jerónimo ${ }^{41}$. La orientación escatológica aparecía clara en los autores africanos ${ }^{42}$.

Aun admitiendo, cosa no habría que probar en cada caso, que san Agustín tuviera un conocimiento suficiente de las fuentes de esa tradición ascético-monástica a la hora de componer el praeceptum, lo que sorprende no son, una a una, las coincidencias señalas, sino el conjunto de ellas. Pero todavía sorprende más otro conjunto de temas en que coincide el escrito agustiniano con el jeronimiano que carecen de historia previa. Por ejemplo, parece realidad novedosa en la tradición ascético-monástica enorgullecerse de la categoría social de la propia familia ${ }^{43}$, la indicación de lo que ha de hacer el asceta o monje cuándo ha acabado la tarea que tenía asignada ${ }^{44}$, la alusión al ruido o alboroto en el refectorio durante la comida ${ }^{45}$, la mención del ardor de la pasión carnal, el no ver crueldad en la sanción de una falta ${ }^{46}$, la referencia a la polilla que puede dañar la ropa ${ }^{47}$.

Habida cuenta de la doble serie de datos nos parece razonable concluir que, a la hora de componer su praeceptum, el obispo de Hipona halló inspiración en la carta jeronimiana. El peso de la prueba cae, primero, en el número elevado de coincidencias, considerada la reducida extensión de ambos escritos, sobre todo del praeceptum, y, segundo, en la novedad que representan algunos temas en que se dan coincidencias.

\section{Las diferencias}

Pero si las coincidencias son muchas, las divergencias no son menos. Nos referimos exclusivamente a las que aparecen en la utilización de los temas

41 Tertuliano, ad uxorem 1,4; ORÍGENEs, hom. in Cant. 1,2; comm. in Rom. 6,1; hom. in Gen 8,3: ADKIN, p. 142.

${ }^{42}$ S. CYPRIANO, de habitu uirginum, 22; ad Donatum, 5; de dom. orat. 36: ADKIN, p. 408.

${ }^{43}$ Vanagloriarse de las propias riquezas no es un topos en los escritos de este estilo (no obstante, cf. Cyprianus, de habitu uirginum 10) y no se conoce antes de la carta 22 de san Jerónimo el jactarse de la nobleza del propio linaje. El tema vuelve a aparecer en PELAGIO, ep. Ad Demetriadem 22 y en S. SEVERo, epist. 2,16: ADKIN, p. 250.

${ }^{44}$ Esta indicación no se halla en escritos anteriores a san Jerónimo: ADKIN, p. 335, que alude también a de opere mon. 29,37.

${ }^{45}$ El silencio (no hablar) durante la comida es tema tradicional, no tanto el no meter ruido o alborotar (cf. DE VoGUÉ, Histoire littéraire, 1,302): ADKIN, p. 328.

${ }^{46}$ AdKIn, p. 318 da como referencia a Paulino de Péregueux en su Vita Martini 6,263. Pero el poeta pertenece a la segunda mitad del s. V, por tanto anterior a los textos que nos ocupan.

${ }^{47}$ Además del texto de san Jerónimo, Adkin señala un apunte parecido en Gregorio Nacianceno (or. 14,16). 
en que, según hemos visto, convergían ambos escritos. Antes de extraer conclusiones, señalemos las más significativas:

- San Jerónimo se sirve de una cita paulina, san Agustín de otra: así en $\mathrm{n}^{\circ} 4^{\circ}$ sobre la oración: aquel cita 1 Tes 5,17; éste Rom 12,12 o Col 4,3.

- San Jerónimo da razón de su precepto, san Agustín, no: así en $n^{\text {os }} 4^{\circ}$ (por qué la distribución en el tiempo de la oración), y $6^{\circ}$ (por qué de los privilegios a algunos grupos).

- San Jerónimo entra en detalles, san Agustín no: así en $n^{\circ} 5^{\circ}$ (cuáles son las horas litúrgicas de rezo), en $n^{\circ} 6^{\circ}$ (el vino); en $n^{\text {os }} 9^{\circ}$ y $10^{\circ}$ (el porte exterior).

- San Jerónimo no señala el lugar de la actividad aludida, san Agustín sí (el oratorio): es el caso en $\mathrm{n}^{\mathrm{o}} 5^{\circ}$.

- San Jerónimo especifica los días de la semana en que se realiza cierta actividad (todos, salvo el domingo), san Agustín no: es el caso en $n^{\circ} 5^{\circ}$.

- San Jerónimo indica dos actividades (lectura y oración), san Agustín sólo una (la oración, de la que está hablando): es el caso en $\mathrm{n}^{\circ} 5^{\circ}$.

- San Jerónimo refiere que no se hacía algo (meter ruido en el refectorio), san Agustín prescribe que no se haga eso mismo: es el caso en $n^{\circ} 7^{\circ}$.

- San Jerónimo usa un verbo de significado genérico (hablar), san Agustín uno más específico (discutir): es el caso en $\mathrm{n}^{\circ} 7^{\circ}$.

- San Jerónimo se muestra intransigente ante las debilidades físicas (en alimentación, vestido, descanso); san Agustín, condescendiente: es el caso en $\mathrm{n}^{\circ} 8^{\circ}$.

- San Jerónimo restringe las salidas de casa, san Agustín orienta sobre el modo de hacerlas: así en $\mathrm{n}^{\circ} 11^{\circ}$.

- San Jerónimo describe una situación negativa para la salvaguarda de la castidad, san Agustín legisla para que no llegue a producirse: es el caso en el $n^{\circ} 12$ (ciertas visitas domésticas / regula las salidas de casa) y en el $n^{\circ} 13$ (ciertas actitudes con animo seductor / evitar ciertos comportamientos que miran al mismo fin).

- San Jerónimo aduce Mt 5,28 a propósito de la mirada impura, san Agustín no: es el caso en $n^{\circ} 15$.

- San Jerónimo habla en general (el grato calor del placer lujurioso), san Agustín en concreto (el ardor placentero de la mirada lujuriosa): así en $n^{\circ} 16$.

- San Jerónimo se refiere al aparecer de pensamientos lujuriosos, san Agustín al aparecer de la mirada lujuriosa: así en n 17 .

- San Jerónimo se refiere a la sanción de una determinada falta (acumular dinero), san Agustín a la sanción de otra distinta (una mirada lujuriosa): así en el $\mathrm{n}^{\circ} 20$. 
- San Jerónimo no indica el lugar donde se puede producir el daño, san Agustín sí (en el corazón y en la comunidad): así en n ${ }^{\circ} 20$.

- San Jerónimo señala el efecto positivo de la sanción ya producido (Egipto se llenó de pánico); san Agustín, el efecto negativo que trata de evitar (contaminación del corazón entero del monje, y de la comunidad): es el caso en $n^{\circ} 20$. San Jerónimo asigna a la sanción de la falta un valor ejemplarizante, san Agustín un valor de prevención.

- San Jerónimo se queda en la negación (no manifiesta crueldad), san Agustín a la negación añade la afirmación (no manifiesta crueldad sino misericordia): es el caso en $\mathrm{n}^{\circ} 20$.

- Del hecho de que la polilla puede dañar la ropa san Jerónimo saca una conclusión (hay que desprenderse de ropa), san Agustín otra (hay que ponerla en común para su cuidado): así en nº 22.

- San Jerónimo asigna al mayordomo del monasterio la tarea de distribuir la ropa a los monjes, san Agustín la asigna al prior: así en $\mathbf{n}^{\circ} 22$.

- San Jerónimo señala una dificultad para poner la ropa en común (la incertidumbre del futuro), san Agustín otra (voluntad de mantener la propia categoría social): así en $\mathrm{n}^{\circ} 24$.

- San Jerónimo habla de compartir los bienes con Cristo (en la persona de los pobres), san Agustín de compartirlos con la comunidad: así en nº 24 .

- San Jerónimo contempla dos preocupaciones alternativas (que la ropa esté limpia o que esté sucia), san Agustín sólo una (que esté limpia): así en $\mathrm{n}^{\mathrm{o}} 26$.

- San Jerónimo aduce una motivación social de su norma sobre la limpieza del vestido (no llamar la atención), san Agustín una motivación moral (evitar manchas en el alma, sin indicar cuáles): así en $\mathrm{n}^{\circ} 26$.

La pregunta surge ahora espontánea: tan numerosas divergencias advertidas en el modo de tratar los mismos temas uno y otro autor, ¿no bastan por sí solas para cuestionar, cuando menos, la dependencia, aceptada anteriormente, del praeceptum agustiniano respecto de la carta jeronimiana? Tal conclusión sería errónea, siempre que esa dependencia se entienda como simple inspiración. Basta con aceptar que el texto de san Jerónimo pudo haber inspirado a san Agustín tratar en el suyo un determinado número de temas. A partir de ahí, el monje hiponense se sintió libre para hacerlo de la forma que más se ajustaba a su modo de ser, a su proyecto monástico y a las circunstancias concretas de su comunidad. En ningún modo se sintió supeditado a las propuestas concretas que halló en el escrito jeronimiano. El obispo de Hipona fue siempre espíritu creador. Lo que recibía de otros solía devolverlo transformado, dejando en el producto la impronta 
de su propia personalidad. En el plano psicológico era grande la diferencia entre él y san Jerónimo, lo que explica actitudes diferentes ante un mismo hecho; en el plano espiritual tenía tras de sí una larga historia de vivencias personales que podían orientar sus opciones en una dirección específica, distinta de la de san Jerónimo; en el plano práctico disponía ya de suficiente experiencia de lo que comportaba una vida monástica cenobítica que aún no poseía san Jerónimo en el momento de escribir la carta 22; en el plano literario contaba con recursos más que suficientes para hablar de lo mismo que otro autor de forma diferente. Estos factores pueden dar razón de las diferencias en el modo de tratar los mismos temas por parte de san Agustín.

Pero lo subjetivo ha de ser completado con lo objetivo. En efecto, un mismo principio puede encontrar diversas encarnaciones prácticas; una misma idea puede tener diversas aplicaciones, todas válidas; una misma reflexión puede acabar en propuestas diferentes, dependiendo de diversos factores. Y en el caso presente no son pocos los que se pueden señalar:

- El diverso género literario de los escritos: un código monástico, el agustiniano, y una carta exhortatoria, que incluye una parte de información histórica sobre el monacato egipcio (parágrafos 33-36 de la carta), el jeronimiano.

- La distinta extensión, mucho menor la del escrito agustiniano que la del jeronimiano.

- Los distintos destinatarios: una joven que practica un tipo de vida ascético vivida en el mundo ${ }^{48}$, en el caso de la carta, y una comunidad monástica masculina, en el caso del praeceptum.

- La distinta magnitud de comunidad monástica: reducida la agustiniana ${ }^{49}$, mucho más numerosas las egipcias (sólo por lo que se refiere a la información sobre el monacato egipcio) $)^{50}$.

\footnotetext{
${ }^{48}$ Aunque tenía esclavas como compañeras de vocación (cf. ep. 22,29), el grupo no es equiparable a una comunidad monástica. Refiriéndose al grupo de Eustoquia, A. de Vogüé habla de "un embrión de comunidad" (Histoire littéraire, I, 257-259).

${ }^{49}$ No disponemos de datos sobre el número de miembros de la comunidad destinataria del Praeceptum, pero el hecho de que el legislador considere que pueden bastar uno o dos monjes para cuidar de la ropa a fin de que no se apolille (Praeceptum 5,1), permite suponer que no era muy numerosa.

${ }^{50}$ Así hay que entender el dato aportado por san Jerónimo de que "están divididos por decurias y centurias". "La mention du centessimus n'en a pas moins son utilité: elle évoque la taille énorme du coenobium. Celle-ci sera confirmée par Sulpice Sévère, selon lequel les monastères d'une centaine de moines sont les plus fréquents, mais on en trouve aussi de deux et trois mille" (A. DE VoGÜÉ, Histoire littéraire, I, p. 297, citando Dial. I, 17).
} 
- La diferente realidad sociológica de los monasterios: contar o no con ancianos y niños.

- Los diversos status eclesiales de las personas: clérigos o monjes, o simples ascetas.

Todas estas variables hacen comprensible la diversidad señalada en el modo de tratar un mismo tema. Si cualquier persona intenta adaptarse a las diversas situaciones, san Agustín no podía ser menos. Consideramos, pues, que las divergencias señaladas, no obstante ser significativas, no bastan para cuestionar la inspiración jeronimiana del praeceptum agustiniano. Encaja perfectamente con el modo habitual de proceder del obispo de Hipona. Una cosa es tomar materiales de otro edificio y otra reproducir más o menos el edificio del que se han tomado los materiales. San Agustín ha tomado de la carta de san Jerónimo abundante material con el que él ha construido su personal edificio, con estructura propia: su código monástico ${ }^{51}$.

Para concluir: admitir la inspiración de san Agustín en el escrito de san Jerónimo no significa asumir que fuera intencional, que el monje de Hipona lo hubiera tomado de forma consciente como guía para componer el praeceptum. No cabe pensar que, antes de ponerse a escribirlo, el santo haya releído la carta jeronimiana buscando iluminación. Habida cuenta de su prodigiosa memoria, hay que decir que no lo necesitaba; le bastaba la lectura hecha tiempo atrás para la composición de su obra De moribus ecclesiae catholicae, sobre todo si se acepta -como propone J. K. Coyle ${ }^{52}-$ que fue compuesta en diferentes momentos y que su parte final, precisamente aquella en que aduce contra los maniqueos información tomada de la carta jeronimiana, fue escrita una vez regresado a África e instalado ya en su ciudad natal, Tagaste ${ }^{53}$.

${ }^{51}$ No deja de ser significativo que el único capítulo del que no hemos señalado ninguna coincidencia con el escrito jeronimiano sea el séptimo del Praeceptum. La distinta magnitud de las comunidades monásticas de Egipto y de la hiponense, unida a la distinta estructura administrativa, reclamaba una forma diversa de gobierno. Por ello al obispo de Hipona no le llamaron la atención tales estructuras y las pasó por alto en su propuesta de comunidad. A su comunidad le bastaba con disponer de un prepósito, y no necesitaba un padre ayudado por decanos.

52 Cf. Augustine's “de moribus ecclesiae catholicae”, pp. 93-94.

${ }^{53}$ Además de lo dicho, el orden en que aparecen los temas en uno y otro escrito es distinto; basta con fijarse en los textos transcritos en la primera sección. Los temas comunes aparecen en distintas partes de uno y otro documento. 